AperTO - Archivio Istituzionale Open Access dell'Università di Torino

\title{
Alpine freshwater ecosystems in a protected area: a source of diatom diversity
}

\section{This is the author's manuscript}

Original Citation:

\section{Availability:}

This version is available http://hdl.handle.net/2318/132819

since

Published version:

DOI:10.1007/s10750-012-1114-0

Terms of use:

Open Access

Anyone can freely access the full text of works made available as "Open Access". Works made available under a Creative Commons license can be used according to the terms and conditions of said license. Use of all other works requires consent of the right holder (author or publisher) if not exempted from copyright protection by the applicable law. 


\section{(3) \\ UNIVERSITÀ DEGLI STUDI DI TORINO}

Elisa Falasco, Luc Ector, Elisabetta Ciaccio, Lucien Hoffmann, Francesca Bona (2012) - Alpine freshwater ecosystems in a protected area: a source of diatom diversity. Hydrobiologia 695 (1) :233-251.

The final publication is available at Springer via http://dx.doi.org/10.1007/s10750-012-1114-0 


\section{Alpine freshwater ecosystems in a protected area: a source of diatom diversity}

Elisa Falasco · Luc Ector · Elisabetta Ciaccio · Lucien Hoffmann · Francesca Bona

E. Falasco $(\square) \cdot$ E. Ciaccio $\cdot$ F. Bona

DBAU, University of Turin, via Accademia Albertina 13, I-10123 Turin, Italy

e-mail: elisa.falasco@unito.it

E. Falasco $\cdot$ L. Hoffmann $\cdot$ L. Ector

Department Environment and Agro-biotechnologies (EVA), Public Research Center - Gabriel Lippmann, Rue du Brill 41, L-4422 Belvaux, Luxembourg

Keywords Alpine lake · Diatoms · Maritime Alps · Reference community $\cdot$ Springs

"This paper has not been submitted elsewhere in identical or similar form, nor will it be during the first three months after its submission to Hydrobiologia." 


\section{Abstract}

The "All Taxa Biodiversity Inventories" (ATBIs) project coordinated by the European Distributed Institute of Taxonomy (EDIT) aims to achieve a baseline biodiversity assessment of flora and fauna in those regions characterized by a lack of knowledge and a high potential for biodiversity. Within the framework of the ATBIs, the aim of the present study was to analyse the diatom flora and ecology of a complex of freshwater ecosystems in the Maritime Alps Natural Park (Italy), designated as a Special area of Conservation under the European Habitat Directive. We sampled epilithic and epiphytic diatoms in different habitats in 24 sites: shallow lake, springs and streams. Our analysis resulted in a list of 138 diatom taxa, highlighting the great biodiversity and the complex structure of the investigated diatom communities. The taxa list included a wide range of uncommon species, including some recorded for the first time in North-Western Italy. Among the different habitats the highest level of diversity was found in the more lentic waters, in particular in limnocrene springs. These results show that the diatom communities of pristine and undisturbed high mountain environments are rich and complex, despite the severe environmental conditions. 


\section{Introduction}

The European Water Framework Directive (2000/60) recognizes the biological and ecological value of freshwater ecosystems, with the view of promoting the sustainable use of these resources and their preservation. Over the last years, an increasing awareness of the importance of biodiversity has led governmental agencies and the scientific community to improve the knowledge and management of these ecosystems in order to preserve their integrity.

Even in high mountains, where species richness tends to be limited due to extreme environmental conditions (Chapin \& Körner, 1995), headwaters are characterized by high levels of biodiversity in relatively small areas, reflecting their high habitat heterogeneity. High mountain springs must be considered as fragile ecosystems. At a local level, the main threats include: habitat reduction due to the increase of pastures, establishment of artificial snow basins, and construction of roads. From a global point of view, an increase in temperature, lengthening of the growth season, habitat fragmentation and alteration of the snow free-period duration are the most important ecological factors affecting high mountain ecosystems. As far as climatic warming and global changes are concerned, mountain regions are among the most potentially vulnerable areas, thus being strongly affected by species loss (Körner, 1995).

Epilithic diatom assemblages in Alpine lacustrine ecosystems have been rarely studied despite their key role in inorganic nutrient cycling, e.g. phosphorus and silica (Loeb et al., 1983; Sánchez-Castillo et al., 2008). High mountain lakes are generally considered as pristine environments, although, human influence has become more and more important in recent years (Cantonati et al., 2006). Several studies on the diatom flora colonizing springs have been carried out in the Eastern Alps, in particular in the Trentino region (Cantonati, 1998a, 1999, 2001; Cantonati \& Ortler, 1998; Cantonati \& Pipp, 2000) and in the Apennines (Dell'Uomo, 1986; Dell'Uomo \& Torrisi, 2000). Due to their pristine conditions, geochemical factors are considered as the driving force influencing diatom assemblages (Cantonati, 1998a; Rimet et al., 2007). However, stream origin and anthropogenic activity also must 
be considered as an important component (Robinson et al., 2010). Spring diatom samples are often characterized by a high number of uncommon or rare taxa, whose ecological preferences are in part still unknown (Reichardt, 1994, 1995; Cantonati, 1998b), and which often present a noncosmopolitan distribution (Sabater \& Roca, 1992). Moreover, due to the peculiar environmental conditions, the finding of new diatom taxa are common (Cantonati, 1998b; Cantonati \& LangeBertalot, 2006, 2009).

In the Italian Alps, high mountain rivers are directly affected by human impacts. Morphological alterations, such as channelization, flow regulation, bank modification and construction of artificial riparian areas represent threats to the physical integrity of high-altitude streams, with important consequences for biological communities, and especially diatom assemblages (Bona et al., 2008). Local alterations in rivers lead to the loss of species (Maddock, 1999), and communities inhabiting such modified stretches are mainly young and pioneering, lacking the late successional components (Bona et al., 2008).

In order to increase the knowledge about the biodiversity in "focal points", the "All Taxa Biodiversity Inventories" (ATBIs) project, coordinated by the European Distributed Institute of Taxonomy (EDIT), is carrying out research in the Maritime Alps Natural Park (North-Western Italy), an area protected by the European Habitat Directive. The ATBIs have been established with the aim of achieving a baseline biodiversity assessment of flora and fauna in those regions characterized by both lack of knowledge and high potential for biodiversity. Water bodies of a protected Alpine region correspond well to these criteria. Besides the important taxonomic value of the project, ATBIs will provide important ecological information on the distribution, abundance and biology of the species recorded, through the collaboration of 27 European scientific institutes.

Within the ATBIs project, we analysed the diatom communities of Italian freshwater ecosystems located in two different valleys in the Maritime Alps Natural Park. We focused on one permanent freshwater lake, permanent rivers, and springs, the latter belonging to rheocrene, limnocrene and 
helocrene typologies as reported by Cantonati (1998b). This study is the first research analysing and comparing diatom biodiversity in lotic and lentic ecosystems in the Italian Western Alps. The aims of our research were i) to analyse diatom communities colonizing different water bodies of two valleys in the Maritime Alps Natural Park from a taxonomic and ecological point of view; ii) to assess and compare biodiversity in different freshwater ecosystems (lake, rivers and springs) and iii) to highlight the presence of rare and endemic species. 


\section{Materials and methods}

\section{Sampling sites}

The Maritime Alps Natural Park (North-Western Italy) (Figure 1a) has been twinned with the French Mercantour National Park since 1987. These Parks enclose an Alpine area of 100,000 ha, recognised to preserve an inestimable natural heritage in terms of flora and fauna.

In this research, we focused on two valleys in the Italian Park (Figure 1b): Gesso della Valletta and Lourousa valleys, both located in the Argentera Cristalline Massif and characterized by metamorphic rocks. The vegetation of the two valleys is composed of broad-leaved (Acer pseudoplatanus L., Alnus viridis (Chaix) DC., Fagus sylvatica L.), coniferous Alpine species (Larix decidua L., Pinus cembra L.) and shrubs (Rhododendron ferrugineum L., Vaccinium vitis-idaea L.). The vegetation surrounding the sampled wetlands was mainly hygrophilous, composed of Alchemilla vulgaris L., Dactylorhiza maculata (L.) Soó, Eriophorum latifolium Hoppe, and Polygonum bistorta L.

Due to the lack of data about diatoms in the Maritime Alps Natural Park, we chose a systematic sampling with $40 \mathrm{~m}$ minimal distance between transects. In particular, we followed a modified stratified-random design as proposed by Croft \& Chow-Fraser (2007). At each sampling site, we identified and sampled all the freshwater habitat zones present in order to have a complete view of species inhabiting the site, thus highlighting their biodiversity and richness. Distances between transects were established by means of a telemeter Bushnell Yardage Pro compact 800. Sampling sites in Gesso della Valletta valley (Figure 1c) were located in Pian della Casa (around 1700 m a.s.l.) and have a sampling area of ca.14 ha. Within this area, we completed 12 transects at $100 \mathrm{~m}$ intervals, sampling all water bodies along the track. In total, we collected 15 samples: 10 from the main river (Gesso della Valletta River) and 5 from the surrounding springs (1 limnocrene, 2 helocrene and 2 rheocrene springs). 
Sampling sites in Lourousa Valley (Figure 1d) were located nearly $1950 \mathrm{~m}$ a.s.l. and the sampling area cover 5.33 ha. Within this area, we completed 8 transects, $40 \mathrm{~m}$ apart one from the other, sampling all freshwater bodies along the track. In total, we collected 9 samples: 2 from the main river (Lourousa River), 3 from the littoral zone of the lake (Lagarot di Lourousa) and 4 from the surrounding springs, all limnocrenes.

\section{Physical and chemical factors}

At each sampling site, we recorded the main physical and chemical parameters. In the field, we recorded UTM coordinates (ED50) by means of a GPS Etrex Garmin. We measured pH, water temperature $(T)$, conductivity (COND), turbidity (TURB), and dissolved oxygen (DO) by means of the probe Hydrolab Quanta. We also estimated water depth (DEPTH) at each sampling site. Chemical analysis of water samples was performed in the laboratory by means of a Lasa 100 spectrophotometer. In particular, we determined calcium ion concentration (Ca), hardness (HARDNESS), nitrates $\left(\mathrm{N}-\mathrm{NO}_{3}\right)$, soluble reactive phosphorous (SRP), and biological oxygen demand $\left(\mathrm{BOD}_{5}\right)$.

\section{Diatom sampling}

At each site, epilithic and epiphytic diatoms were collected in one composite sample following the standardized procedure of Kelly et al. (1998) by scraping cobbles or brushing and squeezing macrophytes. We identified diatoms with the help of light and scanning electron microscopy. Each sample was analysed, identifying each species recorded on the glass slide and, after that, counting 400 valves per sample. Species were identified in accordance with Krammer \& Lange-Bertalot (1986, 1988, 1991a, 1991b), Simonsen (1987), Lange-Bertalot (1993, 2001), Lange-Bertalot \& Metzeltin 
(1996), Krammer (1997, 2000, 2002, 2003), Reichardt (1999), Werum \& Lange-Bertalot (2004), Metzeltin et al. (2005), and Levkov et al. (2007).

\section{Statistical analysis}

We estimated diatom diversity using the Shannon diversity index and evenness. We applied the nonparametric Kruskal-Wallis test to highlight statistic differences among physico-chemical parameters and Spearman correlation to underline correlations among them. To analyse diatom community composition in relation to physical and chemical parameters, we performed Twinspan analysis (Hill, 1979; Gauch \& Whittaker, 1981) and Canonical Correspondence Analysis (CCA) (ter Braak, 1986) by means of PC-ORD software (McCune \& Mefford, 1999). For the multivariate analysis, we selected the most abundant diatom taxa (taxa showing at least $2 \%$ of total abundance, at least once in the whole collected samples), and the most variable environmental parameters (7VAR, DEPTH, BOD5, HARDNESS, SRP). Note that 7VAR grouped under one parameter Altitude, $\mathrm{Ca}, \mathrm{COND}, \mathrm{DO}, \mathrm{N}-\mathrm{NO}_{3}, \mathrm{pH}$ and TURB because they were highly correlated. 


\section{Results}

\section{Physical and chemical factors}

According to water quality standards proposed by Italian law (D. Lgs. 152/99), the water quality of the three habitat typologies is considered as good (Table 1). In particular, $\mathrm{pH}$ ranged from near neutral (6.9) to slightly basic values (8.4) in springs. Conductivity values were low in all the samples, never exceeding $48 \mu \mathrm{S} / \mathrm{cm}$. The low calcium concentrations confirmed the siliceous character of the waters of the two valleys. Ortho-phosphates were always very low, with mean values below $0.005 \mathrm{mg} \mathrm{SRP} / \mathrm{L}$ in the lake, $0.018 \mathrm{mg} \mathrm{SRP} / \mathrm{L}$ in the rivers, and $0.007 \mathrm{mg} \mathrm{SRP} / \mathrm{L}$ in the springs. Nitrates were slightly higher, with mean values of $0.709 \mathrm{mg} \mathrm{N} / \mathrm{L}$ in the lake, $0.424 \mathrm{mg} \mathrm{N} / \mathrm{L}$ in the rivers and $0.462 \mathrm{mg} \mathrm{N} / \mathrm{L}$ in the springs. In general, $\mathrm{BOD}_{5}$ results indicated low organic loading. Altitude ranged from 1700 to 1959 m a.s.I., respectively corresponding to Gesso della Valletta and Lourousa.

With regard to physico-chemical parameters, we found significant correlations between altitude and conductivity $\left(\rho=0.693^{* * *}\right)$, altitude and dissolved oxygen $\left(\rho=-0.783^{* * *}\right)$, altitude and nitrates $(\rho=$ $\left.0.767^{* * *}\right)$, altitude and calcium $\left(\rho=0.663^{* * *}\right)$, and altitude and turbidity $\left(\rho=0.631^{* *}\right)$, altitude and $\mathrm{pH}(\rho=0.482 *)$.

Using CCA, we graphed all correlated variables under the vector (7VAR). The correlation between altitude and nitrates reflects the fact that the lake, characterized by higher levels of nitrates, was located at a higher altitude than the other water bodies.

The Kruskal-Wallis test showed differences between the lake, the rivers and the springs in dissolved oxygen, turbidity, hardness and calcium $(p<0.05)$. 


\section{Community composition}

In total, we identified 138 diatom taxa. The complete list of taxa is shown in Annex 1. Several plates illustrating the most representative diatom species are provided in Figures 2-152.

A Kruskal-Wallis test highlighted significant differences in evenness values (Table 2) of the two sampled valleys $(p=0.033)$. Moreover, the number of species $(p=0.015)$ and genera $(p=0.033)$ identified during the counting was significantly higher in springs than in the lake and the rivers (springs $>$ lake $>$ rivers). The most frequent and abundant diatom collected in the rivers and springs was Achnanthidium minutissimum, which on average represented $40 \%$ of the communities. Besides Achnanthidium pyrenaicum and A. minutissimum, the most abundant taxa in the lake were Denticula tenuis, Encyonema minutum, Cymbella excisa, Amphora inariensis and Gomphonema pumilum var. elegans (in order of relative abundance). River diatom communities were generally composed of rheophilous taxa, such as A. pyrenaicum, Diatoma mesodon, Fragilaria arcus, Diatoma hyemalis and E. minutum (in order of relative abundance). Besides A. minutissimum, springs were dominated by $E$. minutum, D. mesodon, D. hyemalis, D. tenuis, A. pyrenaicum, Achnanthidium daonense, Nitzschia cf. fonticola and Encyonema silesiacum. An interesting result of the diatom community analysis was the record of uncommon taxa, especially in springs. In particular, we found several species belonging to the genera Eunotia and Pinnularia as well as the uncommon species Aulacoseira alpigena and Stauroforma exiguiformis.

\section{Diatom community in relation to environmental variables}

Twinspan analysis highlighted 4 different site groups on the basis of diatom composition (Figure 153). In general, the Twinspan dendrogram showed a first separation representing the different geographical locations of the two valleys, at least for $83 \%$ of the cases. The separation is particularly evident for spring sites, although some exceptions. The only limnocrene spring in Gesso della Valletta Valley proved to be closer to the limnocrene springs in Lourousa than to the rheocrene and helocrene 
ones in its own valley. Moreover, the community composition of the rheocrene spring in Lourousa valley was closer to those of the rivers than to those in the other springs, as a result of its lotic character.

On the one hand, spring diatom communities of the two valleys showed a number of differences. Thus, some species such as $D$. hyemalis and Fragilaria rumpens were by far more abundant in Gesso della Valletta Valley, while E. minutum, D. tenuis, N. cf. fonticola and Meridion circulare were mostly restricted to Lourousa Valley. On the other hand, the composition of the communities colonizing river stretches in the two valleys was quite similar. Indeed, we can easily group river sites together in the second group of the Twinspan analysis (Figure 153).

The main summary statistics of CCA are shown in Table 3. The cumulative explained variance was 28.9\%. Axes 1 and 2, evaluated with a Monte Carlo test with 1000 permutations, were highly significant $(p<0.01)$. 7VAR and HARDNESS were strongly related to Axis 1 , while water depth was correlated to Axis 2 (Table 3). Ordination of the sites based on species composition (Figure 154) showed three separate groups generally overlapping with the three sampled ecosystems (lake, rivers and springs).

Species ordination showed that C. excisa, Cymbella excisiformis, Encyonema ventricosum, N. cf. fonticola, and Staurosira pinnata were typical of sites presenting high levels of $\mathrm{pH}$, conductivity, dissolved oxygen, turbidity, nitrates, calcium and hardness. On the other side of the CCA biplot, we found A. alpigena, Brachysira neoexilis, Cocconeis pseudolineata, Diatoma sp., F. rumpens, Fragilaria vaucheriae, Navicula cryptocephala, Nitzschia cf. acidoclinata, Reimeria sinuata and Tabellaria flocculosa. Species characteristic of greater depth (mainly river sites) were Gomphonema calcifugum, C. pseudolineata, whereas A. alpigena, B. neoexilis and M. constrictum were typical of more shallow sites, mainly springs. 


\section{Discussion}

Physico-chemical factors indicated a good water quality in all the sampled areas, as expected by the pristine nature of the two valleys. Even though pasture in Pian della Casa could be considered as a factor potentially affecting the water bodies, no differences in nutrient concentrations have been highlighted in the two valleys. As a consequence, diatom communities were mainly composed of oligotrophic and oligosaprobic taxa, characteristic of the subalpine zone. The most frequently recorded species (i.e. present in at least $50 \%$ of all samples) were $A$. minutissimum, E. minutum, $A$. pyrenaicum, D. mesodon, F. arcus, E. silesiacum, A. inariensis, D. hyemalis, D. tenuis, G. pumilum var. elegans, and $A$. daonense (in order of percentage of occurrence in the samples). In agreement with some authors (Cantonati \& Spitale, 2009; Kawecka \& Robinson, 2008; Robinson et al., 2010), A. minutissimum was the most recorded species, being found in $100 \%$ of the samples. Also, E. minutum was usually found in our samples ( $97 \%$ of occurrence), while it seems to be less frequent in the Dolomiti Bellunesi National Park (Cantonati \& Spitale, 2009), even though it was the dominant taxon in one of the studied springs. In agreement with Cantonati (1998a, b), Kawecka \& Robinson (2008) and Rimet et al. (2007), we highlighted the presence of $D$. mesodon and $D$. hyemalis in most of the samples ( $85.3 \%$ and $61.8 \%$ of occurrence, respectively) and the rheophilous species $F$. arcus in rivers. These taxa are common in streams with intermediate conductivity and alkalinity (Robinson et al., 2010). D. tenuis was mainly recorded in lentic habitats (lake and limnocrene springs) where it represented a consistent percentage of the community, up to $21.5 \%$. In agreement with previous findings $D$. tenuis seems to have a clear preference for shallow water and it is probably tolerant to occasional exposure to air (Cantonati et al., 2009; Robinson et al., 2010).

In general, the recorded species were adapted to low Ca levels, typical of siliceous substrates; for this reason, species typical of carbonate substrates, such as the recently described Achnanthidium dolomiticum Cantonati et Lange-Bertalot (Cantonati \& Lange-Bertalot, 2006), were not found. Even Geissleria gereckei Cantonati et Lange-Bertalot was not detected at all, confirming its preference for 
limestone and for highly shaded habitat (Cantonati \& Lange-Bertalot, 2009). The mean values of abundance of the most frequent diatom taxa in rivers and springs do agree with the percentages found by Cantonati \& Spitale (2009). A. minutissimum was the most abundant species in the samples, representing respectively $40 \%$ and $42 \%$ of the river and spring communities (mean values).

A total of 138 diatom taxa were identified. In general, we recorded the highest number of taxa in springs (62 in total) and, in particular, in limnocrene typology, in agreement with Cantonati (1998b). The faster flow of the rheocrene springs and of the rivers could select for rheophilous taxa, leading to a loss in species number and diversity (Sabater \& Roca, 1992; Maier, 1994; Cantonati, 1998a, 2001; Ghosh \& Gaur, 1998). Moreover, more lentic waters create suitable habitats for macrophyte growth, leading to the colonization of epiphytic and epilithic taxa. According to previous studies carried out in Piedmont and Aosta Valley (Bona et al., 2007, 2008), we observed that such a small sampling area enclosed a wide range of species, even those never recorded in North-Western Italy, thus confirming that samples from siliceous areas are very species rich (Cantonati, 1998b).

As already pointed out in other studies (Cantonati \& Spitale, 2009; Bertrand et al., 1999), some species seem to be restricted to a certain microhabitat or even to a unique sampling site (see Annex 1). In our research ca. $38 \%$ of the recorded species are limited to a unique typology of microhabitats (lake, rivers or springs).

By comparing diatom communities of high mountain streams of Piedmont and Aosta Valley (Battegazzore et al., 2004; Bona et al., 2008) flowing on siliceous substrate, we noticed the peculiarity of taxa recorded in the Maritime Alps Natural Park. The sampled springs surrounding the rivers allowed the development of huge populations of centric diatoms, which often drift into the Gesso della Valletta and Lourousa rivers, increasing their biodiversity. A. alpigena, for instance, is an oligosaprobous species that requires high oxygenation, low conductivity and slightly acid conditions of water (Van Dam et al., 1994). This species had already been recorded in Adamello Park (Cantonati, 1998b) and was very abundant in the Macun Catchment, Switzerland (Robinson \& Kawecka, 2005), 
but it represents a new finding for the Piedmont region. Other interesting taxa especially found in helocrene springs, and rarely recorded during previous surveys, belong to the genera Eunotia and Pinnularia; i.e. Pinnularia borealis var. tenuistriata, Pinnularia sinistra and Pinnularia subcapitata.

In general, all taxa were typical of oligotrophic, oxygen-rich waters with low electrolyte levels and are characteristic of swamps and moors. According to the "red list" diatoms established by LangeBertalot \& Steindorf (1996) for Germany, we can consider $56 \%$ of the recorded species as endangered at various levels. Moreover, we found some threatened taxa important to be protected, in particular extremely rare species (ca. 3\%) such as Amphora fogediana, Craticula dissociata, Navicula tridentula and Stauroneis agrestis, and the highly endangered species Eunotia circumborealis and Navicula detenta. It is important to focus the attention on $A$. inariensis, a species considered as endangered in the red list but particularly frequent in our samples (ca. $61 \%$ of occurrence) even though with low percentages of abundance ( $0.5 \%$ in the river typology, $1.2 \%$ in the springs and $2.2 \%$ in the lake). This emphasises the importance of preserving the integrity of this protected area and its naturalistic value. Lange-Bertalot's red list refers to the German diatom flora and ca. $27 \%$ of the taxa recorded in our research were not included in the catalogue. For this reason, further research specific to the Italian Alpine region is needed.

Multivariate analysis allowed pointing out local and landscape influences on diatom assemblages. On the basis of the community composition and through Twinspan Analysis, we can confirm that the three typologies of sampled habitats were well differentiated. Rivers had similar communities despite their location in different valleys of the Maritime Alps Natural Park. On the other hand, spring diatom communities presented peculiar species composition depending on location. The spring communities are different because of the nature of the two valleys. Lourousa Valley shows a more incised profile in comparison to Gesso della Valletta Valley. Springs were mainly closer to a glacier and exposed to the North in Lourousa, while to the South in Gesso della Valletta. The more shaded nature of the valley coupled with glacial alimentation makes Lourousa springs a harsher environment as far as 
temperature and light supply are concerned (Hieber et al., 2001). Therefore, it is possible to hypothesize that these different environmental conditions have influenced the growth of macrophytes and diatom communities, leading to the differentiation of characteristic assemblages. As a consequence, these natural conditions could influence springs more than rivers. In water bodies of equivalent water quality, local features such as current velocity are the main driving force influencing diatom assemblages. In more lentic habitats, such as springs, microclimatic factors (such as exposure) may play an important role, otherwise neglected in fast flowing systems.

Through the Canonical Correspondence Analysis we showed that altitude, water conductivity, dissolved oxygen, nitrate, calcium, turbidity, $\mathrm{pH}$, hardness and depth are the main variables influencing diatom species distribution. Moreover, the CCA plot, built on the basis of species composition, was effective in discriminating among the different habitats, grouping sites in accordance to the three habitats. Therefore, we can state that there is a good correspondence between the environmental parameters and relative diatom communities in the Maritime Alps Natural Park. 


\section{Conclusions}

This research allowed us to identify the diatom communities inhabiting a pristine high mountain area, providing important information concerning the ecological preferences of some rare species, their abundance and distribution. This study indicates the importance of mountain springs as an important source of biodiversity and niche for rare species. Moreover, the juxtaposition of lotic and lentic waters (such as lakes or limnocrene springs) increases habitat heterogeneity and the potential biodiversity of the area (Robinson \& Kawecka, 2005). Being enclosed in a protected area, Gesso della Valletta and Lourousa valleys should be considered as reference environments, free from any remarkable kind of human pressure. Diatom communities, indeed, have to be considered excellent bioindicators both for long-term changes (such as mountain temperature increase and glacier retreat) and for local human impacts (such as the construction of winter ski resorts and artificial reservoirs). Over the last 20 years, glacier retreat has globally accelerated, with consequences on flow regime and sediment transport. One of the main consequences of global warming in the Alps, will probably be a shift from kryal to rhithral ecosystems with the increase of intermittent and krenal streams (Brown et al., 2007). These will influence the presence, abundance and distribution of the biological communities inhabiting these stretches and the functional characteristics of the Alpine running and standing waters (Robinson et al., 2010).

This research may represent a valid contribution to the use of diatom communities in the environmental assessment of local human impacts. In this context, mountain streams and springs are unusual environments, characterized by atypical environmental features and pressures. Application of common standardized diatom indices appears inadequate to the evaluation of their water quality. For this reason, comparison with a potential reference community is required. In particular, as our research has illustrated, a complex of abiotic parameters, including site exposure, can influence diatom communities colonizing springs. 
The recent need for ecosystem management has led the scientific community to consider the intrinsic natural conservation value besides traditional methods. According to Coesel (2001), biodiversity and species rareness, in connection with ecosystem maturity and replaceability (Schroevers, 1973), should be considered as important parameters in ecosystem assessment. 


\section{Acknowledgements}

This research was partially funded by the European Distributed Institute of Taxonomy (EDIT). In

particular, we would like to thank Marta De Biaggi and the logistic staff of the Maritime Alps Natural

Park for their precious help. 


\section{References}

Battegazzore, M., A. Morisi, B. Gallino \& S. Fenoglio, 2004. Environmental quality evaluation of Alpine springs in NW Italy using benthic diatoms. Diatom Research 19: 149-165.

Bertrand, J., J. P. Renon \& O. Monnier, 1999. Les diatomées des sources du rebord karstique de la Beauce de la région orléanaise. Symbioses 1: 3-14.

Bona, F., E. Falasco, S. Fassina, B. Griselli \& G. Badino, 2007. Characterization of diatom assemblages in mid-altitude streams of NW Italy. Hydrobiologia 583: 265-274.

Bona, F., E. Falasco, S. Fenoglio, L. lorio \& G. Badino, 2008. Response of macroinvertebrate and diatom communities to human-induced physical alteration in mountain streams. River Research and Applications 23: 1-14.

Brown, L.E., A.M. Milner \& D.M. Hannah, 2007. Groundwater influence on alpine stream ecosystems. Freshwater Biology 52: 878-890.

Cantonati, M., 1998a. Diatom communities of springs in the Southern Alps. Diatom Research 13: 201220. 
Cantonati, M., 1998b. Le sorgenti del Parco Adamello-Brenta. Ricerche idrobiologiche su fonti non captate. Parco Documenti 11: 177 pp.

Cantonati, M., 1999. Distribution and seasonality of the phytobenthos along two mountain spring streams in catchments of contrasting lithology. Atti XIII Convegno del Gruppo per l'Ecologia di Base "G. Gadio". Venezia: 25-27 maggio 1996. Supplemento del Bollettino del Museo Civico di Storia Naturale di Venezia, 49 (1998): 357-367.

Cantonati, M., 2001. The diatom communities of the liverwort Chiloscyphus polyanthos var. rivularis in a mountain spring-fed stream in the Adamello-Brenta Regional Park (Northern Italy). In Jahn, R., J. P. Kociolek, A. Witkowski \& P. Compère (eds.), Lange-Bertalot-Festschrift, Gantner, Ruggell: 353-368.

Cantonati, M. \& K. Ortler, 1998. Using spring biota of pristine mountain areas for long term monitoring - Hydrology, Water Resources and Ecology in Headwaters. In IAHS (ed.), Proceedings of the Headwater ' 98 Conference, Meran, Italy, 248: 379-385.

Cantonati, M. \& E. Pipp, 2000. Longitudinal and seasonal differentiation of epilithic diatom communities in the uppermost sections of two mountain spring-fed streams. Verhandlungen der Internationalen Vereinigung für theoretische und angewandte Limnologie 27: 1591-1595. 
Cantonati, M. \& H. Lange-Bertalot, 2006. Achnanthidium dolomiticum sp. nov. (Bacillariophyta) from oligotrophic mountain springs and lakes fed by dolomite aquifers. Journal of Phycology 42: 11841188.

Cantonati, M. \& H. Lange-Bertalot, 2009. Geissleria gereckei sp. nov. (Bacillariophyta) from leaf-litter covered stones of very shaded carbonate mountain springs with extremely low discharge. Phycological Research 57: 171-177.

Cantonati, M. \& D. Spitale, 2009. The role of environmental variables in structuring epiphytic and epilithic diatom assemblages in springs and streams of the Dolomiti Bellunesi National Park (southeastern Alps). Fundamental and Applied Limnology, Archiv für Hydrobiologie 174: 117-133.

Cantonati, M., L. Lapini, S. Paradisi \& F. Stoch, 2006. Conservation and management. In Stoch, F. (ed.), High-altitude lakes, Quaderni habitat, 14: 123-135. Ministero dell'Ambiente e della Tutela del Territorio. Museo Friulano di Storia Naturale.

Cantonati, M., S. Scola, N. Angeli, G. Guella \& R. Frassanito, 2009. Environmental controls of epilithic diatom depth distribution in an oligotrophic lake characterized by marked water-level fluctuations. European Journal of Phycology 44(1): 15-29.

Chapin, F. S. III \& Ch. Körner, 1995. Patterns, causes, changes and consequences of biodiversity in Arctic and Alpine ecosystems. In Chapin, F. S. III \& Ch. Körner (eds.), Arctic and Alpine Biodiversity: 
Patterns, Causes and Ecosystem Consequences, Springer-Verlag, Berlin Heidelberg New York: 313320.

Coesel, P. F. M., 2001. A method for quantifying conservation value in lentic freshwater habitats using desmids as indicator organisms. Biodiversity and Conservation 10: 177-187.

Croft, M. V. \& P. Chow-Fraser, 2007. Development of the wetland macrophyte index to detect degree of water quality impairment in Great Lake coastal marshes. Journal of Great Lakes Research 33 (special issue 3): 172-197.

Dell'Uomo, A., 1986. Diatoms and other algae from the thermal-sulphur springs of Triponzo (Central Italy). Algological Studies 42: 79-91.

Dell'Uomo, A. \& M. Torrisi, 2000. Diatomées de sources et diatomées d'embouchures dans les cours d'eau de l'Apenin central (Italie). Cryptogamie Algologie 21: 247-248.

Gauch, H. G. \& R. H. Whittaker, 1981. Hierarchical classification of community data. Journal of Ecology 69: 537-557.

Ghosh, M. \& J. P. Gaur, 1998. Current velocity and the establishment of stream algal periphyton communities. Aquatic Botany 60: 1-10. 
Hieber, M., C.T. Robinson, S.R. Rushforth \& U. Uehlinger, 2001. Algal communities associated with different Alpine stream types. Arctic, Antarctic and Alpine Research 33(4): 447-456.

Hill, M. O., 1979. Twinspan - A Fortran Program for Arranging Multivariate Data in an Ordered Two Way Table by Classification of the Individuals and Attributes. Ecology and Systematics, Cornell University: Ithaca, NY.

Kawecka, B. \& C.T. Robinson, 2008. Diatom communities of lake/stream networks in the Tatra Mountains, Poland, and the Swiss Alps. Oceanological and Hydrobiological Studies 37(3): 21-35.

Kelly, M. G., A. Cazaubon, E. Coring, A. Dell'Uomo, L. Ector, B. Goldsmith, H. Guasch, J. Hurlimann, A. Jarlman, B. Kawecka, J. Kwandrans, R. Laugaste, E. A. Lindstrøm, M. Leitao, P. Marvan, J. Padisák, E. Pipp, J. Prygiel, E. Rott, S. Sabater, H. Van Dam \& J. Vizinet, 1998. Recommendations for the routine sampling of diatoms for water quality assessment in Europe. Journal of Applied Phycology 10: 215224.

Körner, Ch., 1995. Alpine plant diversity: a global survey and functional interpretations. In Chapin, F. S. III \& Ch. Körner (eds.), Arctic and Alpine Biodiversity: Patterns, Causes and Ecosystem Consequences, Springer-Verlag, Berlin Heidelberg New York: 45-62. 
Krammer, K., 1997. Die cymbelloiden Diatomeen. Eine Monographie der weltweit bekannten Taxa. Teil 1. Allgemeines und Encyonema part. Bibliotheca Diatomologica 36, J. Cramer, Stuttgart: 382 pp.

Krammer, K., 2000. Diatoms of Europe. Diatoms of the European Inland Waters and Comparable Habitats. Vol. 1. The genus Pinnularia. A. R. G. Gantner Verlag K. G., Ruggell: 703 pp.

Krammer, K., 2002. Diatoms of Europe. Diatoms of the European Inland Waters and Comparable Habitats. Vol. 3. Cymbella. A. R. G. Gantner Verlag K. G., Ruggell: 584 pp.

Krammer, K., 2003. Diatoms of Europe. Diatoms of the European Inland Waters and Comparable Habitats. Vol. 4. Cymbopleura, Delicata, Navicymbula, Gomphocymbellopsis, Afrocymbella. A. R. G. Gantner Verlag K. G., Ruggell: 530 pp.

Krammer, K. \& H. Lange-Bertalot, 1986. Bacillariophyceae. 1. Naviculaceae. In Ettl, H., J. Gerloff, H. Heynig \& D. Mollenhauer (eds.), Süßwasserflora von Mitteleuropa 2. G. Fischer Verlag, Stuttgart, New York: $876 \mathrm{pp}$.

Krammer, K. \& H. Lange-Bertalot, 1988. Bacillariophyceae. 2. Bacillariaceae, Epithemiaceae, Surirellaceae. In Ettl, H., J. Gerloff, H. Heynig \& D. Mollenhauer (eds.), Süßwasserflora von Mitteleuropa 2. G. Fischer Verlag, Stuttgart, New York: 596 pp. 
Krammer, K. \& H. Lange-Bertalot, 1991a. Bacillariophyceae 3. Centrales, Fragilariaceae, Eunotiacae. In Ettl, H., J. Gerloff, H. Heynig \& D. Mollenhauer (eds.), Süßwasserflora von Mitteleuropa. 2. G. Fischer Verlag, Stuttgart, Jena: 576 pp.

Krammer, K. \& H. Lange-Bertalot, 1991b. Bacillariophyceae. 4. Achnanthaceae, Kritische Ergänzungen zu Navicula (Lineolatae) und Gomphonema, Gesamtliteraturverzeichnis. In Ettl, H., G. Gärtner, J. Gerloff, H. Heynig \& D. Mollenhauer (eds.), Süßwasserflora von Mitteleuropa. 2. G. Fischer Verlag, Stuttgart, Jena: $437 \mathrm{pp}$.

Lange-Bertalot, H., 1993. 85 neue Taxa und über 100 weitere neu definierte Taxa ergänzend zur Süsswasserflora von Mitteleuropa Vol. 2/1-4. Bibliotheca Diatomologica 27. J. Cramer, Stuttgart: 393 pp.

Lange-Bertalot, H., 2001. Navicula sensu stricto. 10 genera separated from Navicula sensu lato. Frustulia. In Lange-Bertalot, H. (ed.), Diatoms of Europe. Volume 2. Diatoms of the European Inland Waters and Comparable Habitats. A. R. G. Gantner Verlag K. G., Ruggell, Königstein, Germany: 256 pp.

Lange-Bertalot, H. \& D. Metzeltin, 1996. Iconographia Diatomologica. Annotated Diatom Micrographs Vol. 2. Oligotrophie-Indikatoren. 800 Taxa repräsentativ für drei diverse Seen-Typen, kalkreich oligodystroph - schwach gepuffertes Weichwasser. A. R. G. Gantner Verlag K. G., Ruggell, Koeltz Scientific Books: 390 pp. 
Lange-Bertalot, H. \& A. Steindorf, 1996. Rote Liste der limnischen Kieselalgen (Bacillariophyceae) Deutschlands. Schriftenreihe für Vegetationskunde 28: 633-677.

Levkov, Z., S. Krstic, D. Metzeltin \& T. Nakov, 2007. Diatoms of Lakes Prespa and Ohrid. About 500 taxa from ancient lake system. In Lange-Bertalot, H. (ed.), Iconographia Diatomologica 16, Annotated Diatom Monographs, Biogeography-Ecology-Taxonomy. A. R. G. Gantner Verlag K. G., Ruggell: 649 pp.

Loeb, S. L., J. E. Reuter \& C. R. Goldman, 1983. Littoral zone production of oligotrophic lakes. In Wetzel, R. G. (ed.), Periphyton of Freshwater Ecosystems, Junk W. Publishers, The Hague: 161-168.

Maddock, I., 1999. The importance of physical habitat assessment for evaluating river health. Freshwater Biology 41: 373-391.

Maier, M., 1994. Die jahreszeitliche Veränderung der Kieselalgengemeinschaft in zwei geologisch unterschiedlichen Fließgewässern der Alpen und ihre Verteilung auf verschiedenen Substraten. Diatom Research 9: 121-131.

McCune, B. \& M. J. Mefford, 1999. Multivariate Analysis of Ecological Data, Version 4. MjM Software Design, Gleneden Beach, Oregon, USA. 
Metzeltin, D., H. Lange-Bertalot \& F. García-Rodríguez, 2005. Diatoms of Uruguay. Compared with other taxa from South America and elsewhere. In Lange-Bertalot, H. (ed.), Iconographia Diatomologica 15, Annotated Diatom Monographs, Taxonomy-Biogeography-Diversity. A. R. G. Gantner Verlag K. G., Ruggell: 736 pp.

Reichardt, E., 1994. Zur Diatomeenflora (Bacillariophyceae) tuffabscheidender Quellen und Bäche im Südlichen Frankenjura. Berichte der Bayerischen Botanischen Gesellschaft 64: 119-133.

Reichardt, E., 1995. Kieselalgenflora (Bacillariophyceae) des wachsenden Steins von Usterlig. Berichte der Bayerischen Botanischen Gesellschaft 65: 87-92.

Reichardt, E., 1999. Zur Revision der Gattung Gomphonema. Die Arten um G. affine/insigne, G. angustatum/micropus, G. acuminatum sowie gomphonemoide Diatomeen aus dem Oberoligozän in Böhmen. In Lange-Bertalot, H. (ed.), Iconographia Diatomologica 8, Annotated Diatom Monographs. A. R. G. Gantner Verlag K. G., Ruggell: 203 pp.

Rimet, F., J. Gomà, J. Cambra, E. Bertuzzi, M. Cantonati, C. Cappelletti, F. Ciutti, A. Cordonier, M. Coste, F. Delmas, J. Tison, L. Tudesque, H. Vidal \& L. Ector, 2007. Benthic diatoms in western European streams with altitudes above $800 \mathrm{~m}$ : Characterisation of the main assemblages and correspondence with ecoregions. Diatom Research 22: 147-188. 
Robinson, C.T. \& B. Kawecka, 2005. Benthic diatoms of an Alpine stream/lake network in Switzerland. Aquatic Science 67: 492-506.

Robinson, C.T., B. Kawecka, L. Füreder \& A. Peter, 2010. Biodiversity of Flora and Fauna in Alpine Waters. In: Bundi, U. (ed.), Alpine Waters, The Handbook of Environmental Chemistry 6: 193-223.

Sabater, S. \& J. R. Roca, 1992. Ecological and biogeographical aspects of diatom distribution in Pyrenean springs. British Phycological Journal 27: 203-213.

Sánchez-Castillo, P. M., J. E. Linares-Cuesta \& D. Fernández-Moreno, 2008. Changes in epilithic diatom assemblages in a Mediterranean high mountain lake (Laguna de La Caldera, Sierra Nevada, Spain) after a period of drought. Journal of Limnology 76: 49-55.

Schroevers, P. J., 1973. Rapid biological evaluation of aquatic ecosystems. Verhandlungen der Internationalen Vereinigung für Theoretische und Angewandte Limnologie 18: 1736-1741.

Simonsen, R., 1987. Atlas and Catalogue of Diatom Types of Friedrich Hustedt, Vol. I-III. Cramer J., Berlin: $1741 \mathrm{pp}$.

ter Braak, C. J. F., 1986. Canonical correspondence analysis: A new eigenvector technique for multivariate direct gradient analysis. Ecology 67: 1167-1179. 
Van Dam, H., A. Mertens \& J. Sinkeldam, 1994. A coded checklist and ecological indicator values of freshwater diatoms from the Netherlands. Netherlands Journal of Aquatic Ecology 28: 117-133.

Werum, M. \& H. Lange-Bertalot, 2004. Diatomeen in Quellen unter hydrogeologischen und anthropogenen Einflüssen in Mitteleuropa und anderen Regionen. In Lange-Bertalot, H. (ed.), Iconographia Diatomologica 13, Annotated Diatom Monographs, Ecology - Hydrogeology - Taxonomy. A. R. G. Gantner Verlag K. G., Ruggell: 417 pp. 
Annex 1

\begin{tabular}{|c|c|c|c|c|c|c|c|}
\hline \multirow[b]{2}{*}{ Taxon name } & \multirow[b]{2}{*}{ CODE } & \multirow[b]{2}{*}{$\mathbf{R L}$} & \multirow[b]{2}{*}{ River } & \multirow[b]{2}{*}{ Lake } & \multicolumn{3}{|c|}{ Wetland } \\
\hline & & & & & Rheocrene & Limnocrene & Helocrene \\
\hline Achnanthes exigua var. elliptica Hustedt & AEEL & $* *$ & & + & & & \\
\hline Achnanthidium daonense (Lange-Bertalot) Lange-Bertalot, O. Monnier et Ector & ADDA & G & + & + & + & + & + \\
\hline Achnanthidium minutissimum (Kützing) Czarnecki & ADMI & ** & + & + & + & + & + \\
\hline Achnanthidium pyrenaicum (Hustedt) H. Kobayasi & ADPY & $* *$ & + & + & + & + & + \\
\hline Achnanthidium subatomoides (Hustedt) O. Monnier, Lange-Bertalot et Ector & ASAT & $\mathrm{V}$ & + & & & & + \\
\hline Adlafia bryophila (J. B. Petersen) Gerd Moser, Lange-Bertalot et Metzeltin & ABRY & $\mathrm{V}$ & + & + & + & + & + \\
\hline Adlafia minuscula var. muralis (Grunow) Lange-Bertalot & ADMM & NR & + & + & + & + & + \\
\hline Amphora fogediana Krammer & AMFO & $\mathrm{R}$ & + & & & & \\
\hline Amphora inariensis Krammer & AINA & 3 & + & + & + & + & + \\
\hline Aulacoseira alpigena (Grunow) Krammer & AUAL & G & + & & & + & + \\
\hline Aulacoseira distans (Ehrenberg) Simonsen & AUDI & NR & + & & & & \\
\hline Brachysira brebissonii R. Ross & BBRE & $*$ & + & & & + & + \\
\hline Brachysira neoexilis Lange-Bertalot & BNEO & 3 & + & & & + & + \\
\hline
\end{tabular}


Caloneis sp.

Caloneis spec. Nr. 2 in Lange-Bertalot \& Metzeltin

Caloneis tenuis (W. Gregory) Krammer

Cavinula pseudoscutiformis (Hustedt) D.G. Mann et Stickle

Cocconeis euglypta Ehrenberg

Cocconeis lineata Ehrenberg

Cocconeis pseudolineata (Geitler) Lange-Bertalot

Craticula dissociata (E. Reichardt) E. Reichardt

Cyclotella cyclopuncta Håkansson et J.R. Carter

Cymbella cymbiformis Pantocsek

Cymbella excisa Kützing

Cymbella excisiformis Krammer

Cymbella helvetica Kützing

Cymbopleura naviculiformis (Auerswald) Krammer

Denticula tenuis Kützing

Diadesmis laevissima (Cleve) D.G. Mann 
Diatoma hyemalis (Roth) Heiberg

Diatoma mesodon Kützing

Diatoma sp.

Diploneis ovalis (Hilse) Cleve

Encyonema lunatum (W. Smith) Van Heurck Encyonema minutum (Hilse) D.G. Mann

Encyonema lunatum (W. Smith) Van Heurck Encyonema silesiacum (Bleisch) D.G. Mann Encyonema ventricosum (Kützing) Grunow Encyonopsis cesatii (Rabenhorst) Krammer Encyonopsis falaisensis (Grunow) Krammer Eolimna minima (Grunow) Lange-Bertalot Eucocconeis laevis (Østrup) Lange-Bertalot Eunotia arcus Ehrenberg

Eunotia bilunaris (Ehrenberg) Souza

\begin{tabular}{|c|c|c|c|c|c|c|}
\hline DPER & $* *$ & + & + & + & + & + \\
\hline DEHR & $* *$ & + & & + & & + \\
\hline DHIE & $*$ & + & + & + & + & + \\
\hline DMES & $*$ & + & + & + & + & + \\
\hline D sp. & NR & + & + & + & + & + \\
\hline DOVA & V & & + & & & \\
\hline ENLU & NR & & & & & + \\
\hline ENMI & $*$ & + & + & + & + & + \\
\hline ENNG & NR & + & & + & & \\
\hline ESLE & $*$ & + & + & + & + & + \\
\hline ENVE & NR & & + & & + & \\
\hline ECES & NR & & & & & + \\
\hline ECFA & G & + & & & & \\
\hline EOMI & $* *$ & & & + & & + \\
\hline EULA & $*$ & + & + & + & + & + \\
\hline EARC & 2 & & & & + & \\
\hline EUBI & $*$ & & & + & + & + \\
\hline EBOA & NR & & & & + & + \\
\hline
\end{tabular}


Fragilaria arcus (Ehrenberg) Cleve

Fragilaria bicapitata Ant. Mayer

Fragilaria capitellata (Grunow) J.B. Petersen

Fragilaria delicatissima (W. Smith) Lange-Bertalot

Fragilaria gracilis $\emptyset$ strup

Fragilaria rumpens (Kützing) G.W.F. Carlson

Fragilaria vaucheriae (Kützing) J.B. Petersen

Fragilariforma virescens (Ralfs) D. M. Williams et Round

Frustulia rhomboides (Ehrenberg) De Toni

Gomphonema angustatum (Kützing) Rabenhorst

Gomphonema bohemicum Reichelt et Fricke

Gomphonema calcifugum Lange-Bertalot et E. Reichardt

Gomphonema cymbelliclinum E. Reichardt et Lange-Bertalot

\begin{tabular}{|c|c|c|c|c|c|c|}
\hline ECIR & 1 & + & & & & \\
\hline EMIN & * & + & & + & + & + \\
\hline ESOL & G & & + & & & + \\
\hline ESUB & $* *$ & & & & + & \\
\hline ETEN & V & & & & + & \\
\hline FARC & $* *$ & + & + & + & + & + \\
\hline FBIC & $*$ & & & & + & \\
\hline FCCP & NR & & & + & & \\
\hline FDEL & NR & & & & + & \\
\hline FGRA & $*$ & + & & & + & + \\
\hline FRUM & NR & + & & + & + & + \\
\hline FVAU & $* *$ & + & + & + & + & + \\
\hline FFVI & NR & & & & & + \\
\hline FRHO & V & & & + & + & + \\
\hline GANG & $*$ & & & & & + \\
\hline $\mathrm{GBOH}$ & 3 & + & & & & \\
\hline GCLF & NR & + & & & + & \\
\hline GCBC & $r$ & + & & & & + \\
\hline
\end{tabular}


Gomphonema hebridense W. Gregory

Gomphonema mexicanum Grunow

Gomphonema micropus Fricke

Gomphonema minutum C. Agardh

Gomphonema parvulum (Kützing) Kützing

Gomphonema productum (Grunow) Lange-Bertalot et E. Reichardt

Gomphonema pumilum var. elegans E. Reichardt et Lange-Bertalot

Gomphonema sp.

Gomphonema tergestinum (Grunow) Fricke

Gomphonema utae Lange-Bertalot et E. Reichardt

Luticola acidoclinata Lange-Bertalot

Luticola mutica (Kützing) D.G. Mann

Luticola sp.

Mayamea atomus (Kützing) Lange-Bertalot

Melosira varians C. Agardh

Meridion circulare (Greville) C. Agardh

Meridion constrictum Ralfs

Microcostatus krasskei (Hustedt) J.R. Johansen et Sray

\begin{tabular}{|c|c|c|c|c|c|c|}
\hline GHEB & V & & & + & & + \\
\hline GMEX & NR & & & + & & \\
\hline GMIC & * & + & + & + & + & + \\
\hline GMIN & $* *$ & + & & & & \\
\hline GPAR & $* *$ & + & & + & + & + \\
\hline GPRO & D & + & & & + & \\
\hline GPEL & NR & + & + & + & + & + \\
\hline G sp. & $N R$ & & & & & + \\
\hline GTER & G & + & & & & + \\
\hline GUTA & D & & & & + & \\
\hline LACD & $N R$ & & & & + & \\
\hline LMUT & D & & & & + & \\
\hline L sp. & NR & + & & & & \\
\hline MAAT & $* *$ & & & & + & \\
\hline MVAR & $* *$ & + & & & & \\
\hline MCIR & $* *$ & + & + & + & + & + \\
\hline MCON & $* *$ & + & & + & + & + \\
\hline MKRA & NR & + & & & & \\
\hline
\end{tabular}


Navicula angusta Grunow

Navicula antonii Lange-Bertalot et Rumrich

Navicula capitatoradiata H. Germain

Navicula cryptocephala Kützing

Navicula cryptotenella Lange-Bertalot

Navicula detenta Hustedt

Navicula gregaria Donkin

Navicula lundii E. Reichardt

Navicula rhomboides Ehrenberg

Naviculadicta schmassmannii (Hustedt) Werum et Lange-Bertalot

Navicula tridentula Krasske

Navicula tripunctata Bory

Neidium affine (Ehrenberg) Pfitzer

Neidium bisulcatum var. subampliatum Krammer

Neidium longiceps (W. Gregory) R. Ross

Nitzschia cf. acidoclinata Lange-Bertalot

Nitzschia dissipata (Kützing) Grunow

Nitzschia cf. fonticola (Grunow) Grunow

\begin{tabular}{|c|c|c|c|c|c|c|}
\hline NAAN & 3 & & & & + & \\
\hline NANT & NR & + & & & + & \\
\hline NCPR & $* *$ & + & & & & + \\
\hline NCRY & $* *$ & + & & + & + & + \\
\hline NCTE & $*$ & + & & & & \\
\hline NDET & 1 & & & & + & \\
\hline NGRE & $* *$ & + & & & & \\
\hline NLUN & D & + & & + & + & \\
\hline NRBO & V & & & + & + & + \\
\hline NSMM & 2 & + & + & + & + & + \\
\hline NTRI & $\mathrm{R}$ & & & & & + \\
\hline NTPT & $* *$ & + & & & & \\
\hline NEAF & V & & & & + & \\
\hline NBSA & 3 & + & & & & + \\
\hline NLGI & NR & + & & & + & + \\
\hline NACD & $*$ & + & & + & + & + \\
\hline NDIS & $* *$ & + & + & + & + & + \\
\hline NFON & $* *$ & + & + & + & + & + \\
\hline
\end{tabular}


Nitzschia aff. hantzschiana Rabenhorst

Nitzschia pura Hustedt

Nupela imperfecta (Schimanski) Lange-Bertalot et Genkal

Nupela lapidosa (Krasske) Lange-Bertalot

Orthoseira roeseana (Rabenhorst) O' Meara

Pinnularia borealis var. tenuistriata Krammer

Pinnularia interrupta Rabenhorst

Pinnularia microstauron (Ehrenberg) Cleve

Pinnularia microstauron var. rostrata Krammer

Pinnularia perrirorata Krammer

Pinnularia rupestris Hantzsch

Pinnularia silvatica J.B. Petersen

Pinnularia sinistra Krammer

Pinnularia stomatophora (Grunow) Cleve

Pinnularia subcapitata W. Gregory

Pinnularia viridiformis Krammer

Planothidium frequentissimum (Lange-Bertalot) Lange-Bertalot

\begin{tabular}{|lllll} 
NIGR & $*$ & & + \\
NHAN & $*$ & + & + & + \\
NIPR & $*$ & & + & + \\
NUIP & $\mathrm{NR}$ & + & & + \\
NULA & $\mathrm{NR}$ & + & + & \\
OROE & $\mathrm{V}$ & & \\
PBTE & $\mathrm{NR}$ & + & \\
PINT & $\mathrm{NR}$ & & \\
PMIC & $\mathrm{V}$ & + & \\
PMRO & $\mathrm{NR}$ & \\
PPRI & $\mathrm{NR}$ & + \\
PRUP & $\mathrm{G}$ & + \\
PSIL & $\mathrm{V}$ & \\
PSIN & $*$ & + \\
PSTO & $\mathrm{G}$ & + \\
PSCA & $*$ & \\
PVIR & $\mathrm{G}$ & + \\
PTFR & $* *$ &
\end{tabular}


Sellaphora pupula (Kützing) Mereschkowsky

Sellaphora stroemii (Hustedt) H. Kobayasi

Stauroforma exiguiformis (Lange-Bertalot) Flower, V.J. Jones et Round

Stauroneis agrestis J.B. Petersen

Stauroneis anceps Ehrenberg

Stauroneis phoenicenteron (Nitzsch) Ehrenberg

Staurosira pinnata Ehrenberg

Staurosira venter (Ehrenberg) H. Kobayasi

Staurosirella leptostauron (Ehrenberg) D.M. Williams et Round

Surirella angusta Kützing

Surirella linearis W. Smith

Tabellaria flocculosa (Roth) Kützing

Ulnaria acus (Kützing) Aboal

\begin{tabular}{|c|c|c|c|c|c|c|}
\hline PTLA & $* *$ & + & + & + & + & + \\
\hline ALEM & D & & + & & & \\
\hline RSIN & $* *$ & + & & + & + & + \\
\hline SPUP & $* *$ & & & & + & + \\
\hline SSTM & 3 & + & & + & + & + \\
\hline SEXG & NR & + & & & + & + \\
\hline STAG & $\mathrm{R}$ & & & & & + \\
\hline STAN & V & & & + & + & \\
\hline SPHO & V & & & & + & \\
\hline SPIN & $* *$ & + & + & + & + & + \\
\hline SSVE & NR & + & + & + & + & + \\
\hline SLEP & NR & + & & & & \\
\hline SANG & $*$ & & & & + & + \\
\hline SLIN & $*$ & & & & + & \\
\hline TFLO & $* *$ & + & & + & + & + \\
\hline UACU & NR & & & & & + \\
\hline UULN & $*$ & & & & + & \\
\hline
\end{tabular}

Ulnaria ulna (Nitzsch) Compère 
Table 1

\begin{tabular}{|c|c|c|c|}
\hline Parameter & 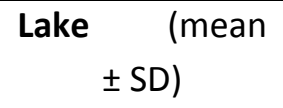 & $\begin{array}{c}\text { Rivers (mean } \\
\pm \mathrm{SD})\end{array}$ & $\begin{array}{c}\text { Springs (mean } \\
\pm \mathrm{SD})\end{array}$ \\
\hline Altitude (m) & $1882 \pm 0$ & $1743 \pm 100$ & $1786 \pm 103$ \\
\hline Depth $(\mathrm{cm})$ & $31.7 \pm 24.7$ & $23.6 \pm 10.4$ & $16.0 \pm 8.5$ \\
\hline Conductivity $\left(\mu \mathrm{S} / \mathrm{cm}^{2}\right)$ & $42.3 \pm 1.2$ & $30.7 \pm 6.1$ & $37.7 \pm 9.3$ \\
\hline Dissolved Oxygen (\%) & $61.0 \pm 2.1$ & $81.3 \pm 3.9$ & $72.6 \pm 9.4$ \\
\hline Dissolved Oxygen (mg/L) & $8.0 \pm 0.37$ & $10.1 \pm 0.63$ & $8.8 \pm 0.87$ \\
\hline $\mathrm{pH}$ & $8.0 \pm 0.15$ & $7.4 \pm 0.21$ & $7.5 \pm 0.50$ \\
\hline Temperature $\left({ }^{\circ} \mathrm{C}\right)$ & $4.5 \pm 0.4$ & $6.5 \pm 2.0$ & $7.8 \pm 3.0$ \\
\hline Turbidity (NTU) & $5.4 \pm 0.5$ & $3.0 \pm 1.9$ & $9.7 \pm 7.9$ \\
\hline BOD $_{5}(\mathrm{mg} / \mathrm{L})$ & $2.15 \pm 1.67$ & $1.24 \pm 0.88$ & $1.88 \pm 1.52$ \\
\hline $\mathrm{Ca}(\mathrm{mg} / \mathrm{L})$ & $9.58 \pm 2.05$ & $3.85 \pm 2.67$ & $6.63 \pm 3.00$ \\
\hline Hardness ${ }^{\circ} \mathrm{dH}$ & $1.34 \pm 0.29$ & $0.77 \pm 0.39$ & $1.12 \pm 0.36$ \\
\hline $\mathrm{Mg}(\mathrm{mg} / \mathrm{L})$ & $0.06 \pm 0.00$ & $1.09 \pm 1.85$ & $0.85 \pm 1.65$ \\
\hline $\mathrm{N}-\mathrm{NO}_{3}(\mathrm{mg} / \mathrm{L})$ & $0.709 \pm 0.172$ & $0.424 \pm 0.115$ & $0.462 \pm 0.211$ \\
\hline $\operatorname{SRP}(\mathrm{mg} / \mathrm{L})$ & $<0.005$ & $0.018 \pm 0.042$ & $0.007 \pm 0.007$ \\
\hline
\end{tabular}


Table 2

\begin{tabular}{|c|c|c|c|}
\hline VALLEY & CODE & SHANNON & EVENNESS \\
\hline \multirow{15}{*}{ Pian della Casa } & R10 & 1.67 & 0.45 \\
\hline & R11 & 2.7 & 0.75 \\
\hline & R12 & 2.4 & 0.61 \\
\hline & R13 & 2.63 & 0.69 \\
\hline & R15 & 2.4 & 0.58 \\
\hline & R17 & 2.6 & 0.67 \\
\hline & R18 & 2.31 & 0.62 \\
\hline & R20 & 2.5 & 0.56 \\
\hline & R23 & 2.37 & 0.52 \\
\hline & R24 & 2.3 & 0.62 \\
\hline & S14 & 2.08 & 0.45 \\
\hline & S19 & 3.06 & 0.66 \\
\hline & S16 & 3.06 & 0.62 \\
\hline & S21 & 2.51 & 0.61 \\
\hline & S22 & 2.61 & 0.63 \\
\hline \multirow{6}{*}{ Lourousa } & R26 & 2.3 & 0.62 \\
\hline & $\mathrm{R} 27$ & 3.1 & 0.79 \\
\hline & S25 & 3.4 & 0.75 \\
\hline & S28 & 2.84 & 0.68 \\
\hline & S29 & 2.62 & 0.67 \\
\hline & S30 & 2.98 & 0.69 \\
\hline
\end{tabular}




\begin{tabular}{c|c|c|c} 
& L31 & 3.01 & 0.7 \\
\cline { 2 - 4 } & L32 & 2.34 & 0.56 \\
\cline { 2 - 4 } & L33 & 2.49 & 0.62 \\
\hline
\end{tabular}


Table 3

\begin{tabular}{lccc}
\hline & Axis 1 & Axis 2 & Axis 3 \\
\hline \hline Eigenvalue & 0.197 & 0.141 & 0.062 \\
Variance in species data & & & \\
$\quad$ Cumulative \% explained & 14.3 & 24.5 & 28.9 \\
$\quad$ Pearson correlation, Spp-Envt & 0.881 & 0.851 & 0.772 \\
Intraset correlation for environmental variables & & \\
ALTITUDE & 0.894 & -0.055 & 0.433 \\
DEPTH & 0.254 & 0.938 & -0.157 \\
SRP & -0.021 & 0.163 & 0.876 \\
BOD5 & 0.181 & -0.227 & -0.148 \\
HARDNESS & 0.538 & -0.068 & 0.259 \\
\hline
\end{tabular}




\section{Figure captions}

Annex 1 Complete list of diatom taxa found in the samples. RL = Red List species (Lange-Bertalot \& Steindorf, 1996). 1 = threatened with extinction; 2 = severely endangered; $3=$ endangered; $V=$ abundance decreasing; $\mathrm{G}=$ presumed endangered; $\mathrm{R}$ = extremely rare; $\mathrm{D}=$ data scarce; * $=$ at present not considered threatened; ${ }^{* *}=$ surely not threatened; $r=$ taxa supposed to be rare on the basis of experience and / or the literature

Table 1 Mean $( \pm S D)$ values of physico-chemical parameters analysed in the three typologies

Table 2 Shannon diversity index and evenness of diatoms in sampled sites

Table 3 Canonical Correspondence Analysis (CCA) axes summary statistics

Fig. 1 Sampling sites location. a. Location of the Maritime Alps Natural Park. b. Location of the two sampled valleys. c. Sampling sites location in Gesso della Valletta Valley. d. Sampling sites location in Lourousa. R=river; S=spring; L=lake

Figs 2-44 Micrographs of some common taxa identified in the samples; scale bar $L M=10 \mu \mathrm{m}$; scale bars SEM = $5 \mu \mathrm{m}$. Figs 2-8 Staurosira venter; Figs 9-14 Stauroforma exiguiformis; Figs 15-20 Diatoma mesodon; 
Figs 21-24 Meridion constrictum; Figs 25-28 Tabellaria flocculosa; Figs 29-33 Meridion circulare; Figs 34-

44 Aulacoseira alpigena

Figs 45-81 Micrographs of some common taxa identified in the samples; scale bar LM = $10 \mu \mathrm{m}$; scale bars

SEM = $5 \mu \mathrm{m}$. Figs 45-55 Achnanthidium minutissimum; Figs 56-58 (59?) Naviculadicta schmassmannii;

Figs 60-63 Achnanthidium daonense; Figs 64-70 Eunotia boreoalpina; Figs 71-78 Eunotia minor; Figs 79-

83 Eunotia tenella

Figs 84-125 Micrographs of some common taxa identified in the samples; scale bar $L M=10 \mu \mathrm{m}$; scale bars SEM = $5 \mu \mathrm{m}$. Figs 84-99 Nitzschia aff. hantzschiana; Figs 100-109 Nitzschia cf. fonticola; Figs 110-119 Nitzschia cf. acidoclinata; 120-125 Denticula tenuis

Figs 126-152 Micrographs of some common taxa identified in the samples; scale bar $L M=10 \mu \mathrm{m}$. Figs 126-128 Encyonema lunatum; Figs 129-131 Encyonopsis falaisensis; Figs 132-135 Amphora inariensis; Figs 136-138 Pinnularia microstauron var. rostrata; Figs 139-140 Pinnularia borealis var. tenuistriata; Fig. 141 Pinnularia microstauron; Figs 142-146 Caloneis tenuis; Figs 147-149 Pinnularia perrirorata; Figs 150-152 Caloneis sp.

Fig. 153 Classification of the sampling sites on the basis of diatom community composition using Twinspan analysis 
Fig. 154 Canonical Correspondence Analysis (CCA) diagram showing diatom species and sampling sites in relation to environmental variables 